\title{
Community Based Diversity Management: Analysis of Community Activities Building Post-Conflict Social Harmony in Tual, Maluku Province, Indonesia
}

\author{
Yance Zadrak Rumahuru; Agustinus C. W. Gaspersz \\ Institut Agama Kristen Negeri Ambon, Indonesia \\ Corresponding Author: rumahuru@yahoo.com
}

\begin{abstract}
Ethnic and religious diversity have often been used as a source of conflict between different groups of people. However, pluralistic societies' local wisdom offers a potential tool for long-term building of peace. This study investigated the practice of diversity management by post-conflict communities in Tual, Maluku Province, Indonesia, along with the factors that support community-based diversity management and forms of activities that contribute to the creation of social harmony in the city. Research was conducted in 2017 through a field study, using qualitative methods to observe the ways in which community groups in the region developed post-conflict social harmony, with data constantly updated to determine the dynamics of diversity management in the community. Two important findings were made. First, shared cultural and historical factors, availability of public spaces for encounters, and traumatic transformation influence and support diversity management and contribute to the creation of social harmony in Tual. And second, several communities were built by community initiatives as the foundation of managing diversity.Community daily activities proved to be effective in ensuring long-term peace building. Based on the reality of social lives in Tual, this study confirmed that a cultural approach is still relevant in efforts to end communal conflict and build social harmony, and synergy between stakeholders is needed to strengthen the social and cultural capital owned by community groups in conflict areas.
\end{abstract}

Keywords: diversity management; social harmony; post-conflict; Tual

\section{INTRODUCTION}

Community pluralism is an indisputable social fact, but often pluralism is a disharmony problem in Indonesia, including the democratic condition in this country (Sofjan, 2016; Hamdi, 2017; Ahnaf and Lussier, 2019). The phenomenon of community life in Indonesia in the last two decades shows that pluralism or ethnic and religious diversity is often used as a reason for conflicts between groups of people with diverse roots and triggering factors. Religion does not produce conflict but in many cases in Indonesia, religion is often constructed to be the dominant factor. The conflicts emerge from various reasons: from criminal actions that are not accepted by certain groups, problems of seizure of resources, to identity politics that emphasize ethnic and religious differences. Among the many factors, it turns out that differences in ethnic and religious identity are more dominant. In fact, ethnic and religious identities are so sensitive that in a number of regions in Indonesia, the conflicts and violence are unstoppable. It proves that diversity as a gift of God turns out to be used by humans as a reason for conflict, mutual destruction, killing, and slaughtering one another without shame. This reality can be found in a number of regions in Indonesia in the last two decades, such as in Kalimantan, Java, Nusa Tenggara, Poso, Maluku and Papua (Mas'oed, Maksum and Soehadha (eds.), 2000; Bertrand, 2004; Trijono et al., 2004; Rumahuru, 2005; 
Mujiburrahman, 2006; van Klinken, 2005 and 2007; Panggabean, 2008; Baron, Azca and Susdinarjanti, 2012). This study, in relation to studies on plural society management and sustainable peace building, wants to show that the pluralistic society of Tual has an interesting local wisdom to offer for the future peaceful Indonesian society.

The study of diversity management and efforts to build social harmony in plural societies have been an important concern of social scientists and the humanities humanities in the last decade with a variety of approaches. The Indonesian Consortium for Religious Studies (ICRS), for example, published the results of a 2013-2016 study in Southeast Asian countries that showed how managing religious and ethnic diversity became an important issue in Southeast Asia (Sofjan, 2016). It can be said that several people involved in the study of managing religious and ethnic diversity, include Nathan (2016), examine the issue of managing ethnic and religious diversity that has implications for public policy and social transformation in Malaysia. Singh and Rajaratnam (2016) review religious, multicultural and salt management issues in Singapore, while Hung (2016) looks at diversity management issues in the form of state policies related to religious affairs in Vietnam. Dionisio (2016) discusses Catholic electoral support as a problem for religious pluralism in The Philippines, and Dhewayani (2016) pays special attention to policy issues and the reality of managing religious diversity in Indonesia.

Researches as mentioned above have shown that Southeast Asia as part of a diverse world full of religions and ethnicities does not always bring benefits to the countries in the region, but also becomes a serious problem, ranging from managing diversity by the people to state policies on diversity that is owned. In almost all regions in Southeast Asia there are problems related to incomplete state policies and regulations towards managing diversity as well as the existence of community groups which are aware of diversity but still tend to be silent. Studies related to diversity management as mentioned before examine more about the existence of religious and ethnic diversity and management policies, especially by the State. This paper wants to see how community groups in conflict areas consciously or unconsciously manage diversity through their daily activities.

Studies on social harmony in Indonesian society focus primarily on the role of actors and the process of the realization of social harmony as conducted by SETARA Institute $(2015,2016$; 2017; Balitbang Kemenag (2016, 2017); Ahnaf ed. (2015)). Studies on diversity management and efforts to build social harmony in conflict communities in Indonesia include Rini Fidiani (2013), Joko Haryanto (2014), Sulaiman (2014), Darwis Muhdina (2015), Mohammad Takdir (2017), Muhammad Arif (2014). The topic of managing diversity in society, both for conflict resolution and for building post-conflict social harmony in Maluku, including in the City of Tual Kei Kecil, has been carried out by Pariela (2008), Rahawarin (2011), Ubra (2016), Soumokil (2011), and Rumahuru, (2005, 20016, 2017; 2019). The studies give attention to the way community groups build relationships, both during the conflict and post-conflict periods. They also explore the efforts made by each group in managing diversity so that diversity does not become a reason for conflict and mutual slaughter as is the case in a number of other regions.

This paper aims to analyze the management of diversity in post-conflict communities in Tual, focusing on how local groups consciously or unconsciously practice diversity management and build social harmony after social conflicts involving different religious groups (Islam and Christianity), by utilizing cultural capital that is owned or creating new social capital - in this writing referred to as community-based diversity management. Furthermore, Tual people, as the subject of this study, have experiences about how differences in community groups were used as reasons for conflict two decades ago. At the same time community groups in Tual also have their own experiences and ways to stop conflict, build peace and develop tolerance, which shows harmony in diversity that needs to be maintained. Community-based diversity management in Tual as intended, attracts study in order to strengthen tolerance and manage diversity from and by communities in conflict areas, as well as to develop theories about the resolution of social conflict in conflicting communities and management of plural societies based on approaches from below, or utilizing cultural capital and social capital that exist in society and are expected to influence policy by formal institutions, including the state, to manage multi-dimensional problems of plural society.

There are two main assumptions in the discussion of this paper. First, the factors that support communitybased diversity management in Tual, and second, the forms of activities of community groups in Tual that look ordinary but have extraordinary impacts and contribute to the promotion of tolerance among religious communities and the management of diversity in plural societies. In conflicts between groups involving people of different religions, it can be seen that religion is the cause of conflict but is also an important factor in building peace (Lindgren 2018). 
This paper is expected to be able to add references related to conflict resolution studies, tolerance between religious communities and diversity management through the use of cultural capital and social capital in managing a plural society such as Indonesia. Along with conflict resolution studies, Aureli (2017) sees that conflict resolution as an integral part of the maintenance of group cohesion. In line with the goal of maintaining social cohesion, Fisher (2015: 582) explains that conflict resolution as the management of differences in a manner that is constructive and cooperative yields outcomes that are mutually satisfactory and have a long-term commitment from the parties. In a similar effort, AbuNimer (2001) offers an intercultural training concept through the presentation of training models in interfaith peace building. Conflict resolution takes a specific form as a mediated agreement, among others, by drawing one or both parties, compromise, surrender, ceasefire, peace agreement, weaponry, constitution, trial, amnesty, excuse, purges, international agreements, apologies, law, topic changes in arguments, and reparations (Wagner-Pacifici $\&$ Hall, 2012). What this suggests shows that conflict resolution is influenced by diverse forms of mediation and is adapted to situations where conflict is taking place. An interesting statement related to social harmony with conflict was written by de Jong \& Twikromo (2017) in their study of the city of Yogyakarta. According to them, the small clashes that occurred in the community were part of the dynamics of everyday urban life.

\section{METHODOLOGY}

Tual, which is used as a place of research, is one of the cities in Indonesia which in 2015-2017 had the best harmony index in Indonesia (Setara Institut, 2015, 2017). In fact, the city of Tual in 1999-2000 experienced a storm of social conflict involving people of different religions killing, destroying and massacring each other. This study was conducted using qualitative research methods with an ethnographic approach and with case studies. Ethnography is intended to diverge field data as it is through observations and interviews that can be presented with an emphasis on the strength of the context of the subject of study, while case studies are intended to see different phenomena in society that can be compared with one another. Respondents from this study are citizens of the city of Tual who are Muslim, Protestant and Catholic. The informants consisted of community leaders, and religious leaders. Those who were informants were previously unknown to the author but through the results of informal observations and talks with the people in Tual, there were a number of names from informants that were widely mentioned. After tracking them, it turned out they are the initiators and actors who are actively conducting peace building activities but do not position themselves as actors or agencies in society.

To obtain the required data, the data collection techniques used are mainly interviews and observations. In addition to observation and interviews, information used as research data was also obtained from written sources or studies of a number of academic article and documents. The technique used in the interview is the snow ball technique. The technique used in observation is to determine the focus of observation on community activities or community groups relations between postconflict indigenous groups in Tual and the changes that can be seen, including observing the daily conditions of people in the city. Because the data of this study are more qualitative, data analysis is performed using interpretive or hermeneutic analysis methods to understand the symptoms examined. All data collected is grouped, interpreted and given meaning. The results of interpretations and/or interpretations as referred to are then presented descriptively and analytically.

\section{FINDINGS AND DISCUSSION}

Referring to the problems and assumptions raised, this study found that first, there are three factors that influence and support the management of diversity and contribute to the creation of social harmony in Tual, namely: (1) shared cultural and historical factors, (2) availability of public spaces for encounters, and (3) traumatic transformation. Second, there are a number of communities in Tual that were built on community initiatives and their activities are the foundation of managing diversity and building social harmony. There are four categories of communities or community groups, namely: (1) indigenous groups of different religious groups, (2) ethnic community groups that have positioned themselves as Tual people, (3) economic interest groups, and (4) hobby groups or similar interests. Their seemingly ordinary activities are known to be effective in managing diversity and enabling social harmony for long-term peace building.

The following explains the supporting factors and forms of activity from each community category in Tual which shows that the community-based approach as practiced by the citizens of Tual can be used as an example of a region in Indonesia that successfully manages diversity management by utilizing cultural capital and social capital as an effective strategy for managing diversity. The reality of diversity management 
in Tual at the same time shows that the Indonesian people have cultural capital which is still deeply rooted in the community and has the potential to be developed to build harmony in society.

\section{Supporting Factors for Community-Based Diversity Management in Tual}

\section{Cultural and historical factors}

What is meant by shared cultural and historical factors here is an awareness of the origins and principles of life that are rooted in the local culture or customs of the Kei people, also known as Evav people. The variables of shared cultural and historical factors are as follows: (1) the relationship of origin (kinship), and (2) cultural values contained in the larvul ngabal law, the philosophy of life such as ain ni ain and maren. ${ }^{1}{ }^{1}$ Cultural and historical factors together are the main supporting factors that are important in terms of managing diversity in the city of Tual, because residents of the city of Tual or Kei Kecil people admit that even though they currently have different religions and beliefs (there are those who embrace Islam, Protestant Christianity and Catholic Christianity), the choice of religion that has occurred since their ancestors could not change their brotherly relations. The following are excerpts of interviews with informants in Tual regarding this matter:

Important factors that support tolerance and diversity management in the city of Tual are family and local wisdom. Katong (us) Kei people have strong family ties. Everyone knows where he comes from (each of them knows his origin), so we cannot act takaruang (carelessly) one against the other (ZB, Tual community leader, interview 28 August 2017).

Katong (us) in Tual, who are both Christian and Muslim, still have an original relationship. We have a customary law, Larvul Ngabal and a custom Ain ni ain. Since long time ago, the elders always tell the story. When conflict occurred in Ambon and there were families who returned here, indeed they were angry that their relatives were also victims of another conflict. However, we could not be angry so long since the heart of Kase Bae Bakalae which teaches us not to be so angry so long for our brother (PF, religious leader in Tual, interview 25 August 2017).

Every generation of Kei or Evav children adheres to the principle of ain ni ain, and vuut ain mehe ni ngivun manut ain mehe ni tilur. ${ }^{2)}$ In this case there is an acknowledgment of the same origin, which can be likened to the use of the term gandong in Central Maluku that refers to those who have a genealogical relationship from the same grandparents. Because they still have blood relations between each other as residents, even though they have different religions or beliefs, they still gather at certain moments and support one another (Ubra, 2011; Derwotubun, 2018).

The origin relationship which is referred to can be understood by looking at the historical setting of Kei people in Tual. Based on the related references it is known that the initial inhabitant at Tual was a king who had fled Bali. His arrival was accepted by the local "native" group that allowed him to stay in the territory of the Petuanan Negeri or Ohoi Taar (Geurtjens, 2016: 336). In addition to the Evav people as indigenous people, other people came from various regions in Southeast Maluku, such as from Luang and the Babar islands and other regions in Maluku. Their arrival in Kei allowed marriages to occur between the sons and daughters of the Evavs and these migrants so that the current generation has the same origins and stories. An informant in his awareness of his origins mentioned that:

We Kei people have blood relations with them from Luang and the Babar Islands because they gave their daughters (daughters) marriage to our male ancestors. Therefore, we highly respect those from our ancestral territories (JJ, community leaders in Tual, interview 11-12-2017).

The cultural values of Kei people as referred to in this study focus on (1) larvul ngabal law, (2) the philosophy of ain ni ain, and (3) the principle of cooperation or maren life. Larvul ngabal law is a customary form of Kei society that regulates respectful living arrangements, including positioning the rights and obligations of each community in every strata of society with a socio-cultural system that is acceptable to everyone. Ain ni ain, often also written as aini-ain, is a value that reminds every descendant of an Evav child of brotherly relations among fellow Kei. This is built from the philosophy of life in Kei, namely: "fuut an mehe ni ngifun" and "manut an mehe ngi tilur", which can be interpreted as: we are all from one offspring or from a single egg, and rip off many eggs and spread throughout the Kei Islands, Southeast Maluku (JD and SL, interviews 10-12-2017; appeal Rahawarin 2011). The philosophy of life as it is called allows various events that occur to be resolved by customary approaches. This also applies to conflict prevention and resolution. Through the philosophy of life as it is called, Kei people build a 
partnership that cares for one another and supports one another, both at home and abroad.

Maren or complete hamaren is a form of cooperation or a system of help to the Kei community, which can be likened to the masohi system among the people of Central Maluku or mutual cooperation among Javanese people which has been generalized into Indonesian culture. Maren has been a value of Kei life since ancestral times. This culture was born from the context of the Kei socio-historical background in the 15 th or 16 th century, as a response from community groups to the shared need to build lives within limitations and to take care of one another. At this time there was interisland mobilization, resulting in encounters, interactions and communication between groups (Ubra, 2011). In the process of interaction and living together as a community, in order to meet common needs, the ancestors practiced a life of mutual help and sharing. Living beings help each other and share with one another, whether for public and collective work or individual work. For example, opening a garden or building a house, building public facilities such as a house of worship, or making a well.

Maren culture is the basis for yelim (or giving) and mutual assistance as a concrete form of cooperation among the Kei people to this date. I got a story from an informant (IR) who with full awareness of the benefits of yelim among the Kei people today says that "for outsiders who don't understand, yelim can be seen as burdensome, but actually yelim is something good and very helpful in both tribes". The form of participation in maren with the yelim system can be in the form of giving thoughts, energy and providing materials needed. Yelim is meant to be the foundation for a life of solidarity, respect, including in terms of stopping conflicts and building a sailing attitude of trust in one another after the conflict.

\section{Availability of Public Spaces for Encounters}

Public space is generally interpreted as a meeting room or a space for open social interaction. The pattern of social interaction is largely influenced by its interaction in the public sphere. Motives and results of interactions in public spaces also vary. Based on the motive then, social interaction in the public sphere accommodates individual interests. On the other hand, the results of interactions in the public sphere can be in the form of fulfilling individual motives or desires, knowledge, opinions, discourse, and value systems (Hardiman, 2004).

Public space encounters in the context of postconflict communities, such as in Tual and most parts of
Maluku, certainly have a significant role. The public sphere of encounter is not merely a space of interaction but also a space for the creation of awareness or mindset, a space for self-recognition in diversity, as well as a space for building dialogical relations between individuals and groups of society so as to enable the building of peace. This is in line with what Habermas (1984) stated about public space, which is a medium for communicating information and views. In this case there is space for people to meet, discuss and debate critically about various aspects, ranging from simple matters, art, economics to politics and power. In Habermas' view, conditions like these contribute to the development of a single society (civil society), because there is intense communication which allows everyone to share interests, goals and values (share value).

In the context of Tual society, the encounter of every individual and group in public spaces as mentioned happens naturally and there is no reluctance to meet the same as in other places whose relationships are full of engineering and there is a great mutual suspicion. This can be experienced and felt when in the Tual area at this time, both during the day and night, almost no one interferes with each other. It is acknowledged that in certain alleys or corners of villages there is a reluctance to cross late at night because there are some people who like to consume alcohol and have the potential to create noise by scaring people who crossed the area. Nevertheless, so far it could be handled so as not to cause conflict.

Referring to the function of public space and the motives underlying social interaction, post-conflict public spaces can be divided into three parts, namely: 1) space for economic activities, 2) space for education, and 3) space for leisure and recreation. In Tual, economic activities are offices (government and private), sea (for fishermen), terminals, traditional markets, and supermarkets. The main education spaces are schools and colleges, while the popular lounge and recreation areas in Tual are parks as well as culinary spots on the Watdek Bridge, GOTA Supermarkets, and long sand panatai. The availability of these public spaces has enabled the encounter of various ethnicities and religions in the region to build post-conflict social communication in their area and also to build mutual trust between one another. This is an important capital to build social harmony and peace. In addition to the availability of physical public space as mentioned, actually it is also necessary to provide public space through media such as newspapers, television, radio and social media that can better advocate for the community. The use of public spaces in encounters as it is called allows dialogue between ethnic and religious 
groups to be more intense and deep (Abu-Nimer, 2001; Swidler and Mojzes, 2000).

\section{Traumatic transformation after conflict}

Experiences of conflict and violence that cause trauma to conflicting societies do not always leave an inner wound that holds a grudge. This study found that the traumatic effects of conflict can be transformed by the community by the way they think about self-improvement and other people (individuals and groups) (Rumahuru, 2017; 2019). There are two important variables in post-conflict traumatic transformations that support the management of diversity and contribute to the creation of social harmony in Tual, namely: 1) feelings of the same fate, and 2) respect for others. The citizens of Tual have a strong collective memory of the conflict that occurred in 1999. Even though the conflict did not last more than one year, it helped to provide their own learning. The same feeling of the same fate was motivated by the awareness of the existence of Kei residents in the city of Tual, both of whom had settled in Tual and later, but who both experienced conflict and felt the bitterness of the conflict situation. Space is limited and there is the threat of death and loss of loved ones or property damage. This context forces community groups to stop the conflict and immediately establish life as before the conflict, despite the various risks. Therefore, there is no other choice but for each warring group to be responsible for the security and survival together in the city of Tual. For the Tual residents of the Evav tribe or the "original Kei" people, the feeling of being in the same boat is also related to the origin of their ancestors, and the strengthening of values in their local life, such as the philosophy of life of Ain Ni Ain and Larvul Ngabal's law.

Conflict in the community can be called a normal thing and may theoretically be necessary for social change to occur in the community, as stated by Lois Couser, but the tragedy of the Maluku conflict that also extended to Tual has shown to the community that conflict causes all people to suffer setbacks. his life. There are many victims of property and human lives. The breakdown of accessibility and leave a prolonged trauma. The collective memory of the community about conflict is an important reason for reorganizing life together by building harmony and managing diversity better.

Appreciation of others by the author is made as its own variable because respect for others is a teaching or value found in the culture of the local community and is also found in the teachings of each religion - even becoming a life principle that can be generally accepted by any group. In the context of this study, respect for others allows acceptance among fellow citizens in the plural City of Tual. Respect for others in Tual is practiced in daily life. One concrete example is respecting and creating a calm situation for each religious follower to perform religious rituals properly without being disturbed by his time. An informant said that as citizens who are Christians, he and his community already understood that at times when prayer would be held, no one would disturb or obstruct. In fact, because he lives around the market and the port near the mosque, when the prayer is being carried out he took the initiative to arrange traffic and parking so it is possible to the Muslim brothers who are doing prayers or worship at the mosque. And vice versa, at religious holidays, voluntarily every young person in Tual is accustomed to taking care of each other during the ceremony or celebration. Respect for others and cooperation between different groups appear simple but have a profound impact on the life of a pluralistic society such as in Indonesia.

\section{Forms of Community Activities that Support Diversity Management in Tual}

This study identifies a number of communities and their activities in the city of Tual which contribute to managing diversity and creating social harmony as follows: (1) indigenous groups and other ethnic groups that have positioned themselves as Tual people, (2) economic interest groups, (3) groups of hobbies or interests alike.

\section{Indigenous groups and other ethnic groups}

The activities of the Kei indigenous groups as well as those outside the Kei group that have been integrated with the culture of the Kei people are clearly visible in religious activities and family celebrations. In this case, different religious groups help one another regardless of the background of their beliefs or faith. In fact, by contributing to helping different religious groups, they consider to have implemented their religious values, while carrying out the mandate of their ancestors to look after one another. Tual communities have activities that can be called one of the best practices for building harmony and managing community-based diversity that is rarely found in other regions. The following two short stories can explain what is meant by this.

\section{Story 1. Building a Mosque and Church in Tual ${ }^{3)}$}

Construction of houses of worship, both mosques and churches, in addition to requiring material capital or large costs, also requires labor. Community groups in the city of Tual overcome these problems by utilizing the cultural 
capital they have. Cultural capital as referred to is the cultural relations of the community which are synergized to alleviate the burden of development faced by certain groups that are carrying out development activities. The way is that the community group that is building a mosque or church states the purpose of the construction or work being carried out to relatives of different religions, or to groups outside the community itself. Those who are told with their own awareness organize themselves and provide assistance according to the needs needed. For example, giving $\mathrm{C}$ minerals (sand and stone) or building materials (wood, iron, cement, etc.) as yelim from certain groups or communities to those who are building. Moreover, when doing work that requires a lot of labor, energy and time is given to help complete the work.

The informant (HK, community leader in Tual) told me that recently there was a renovation of the mosque in the city of Tual, and when they wanted to cast the mosque, Christians in Tual (Protestants and Catholics) offered themselves to participate actively by being involved as workers. Vice versa, when doing construction or renovation of a church building in one of the congregations or parishes, the Muslim brothers in Tual brought their yelim by volunteering to donate material and energy. This reality is different from the model of using paid labor, while at the same time criticizing transactional forms of work in modern society.

Such practices are referred to in the context of a society that has just been in conflict within a religious setting, and consciously or not, has opened boundaries between different religious communities and intensely established communication so as to create mutual respect and trust in one another. The author found a message used by people of different religions in Tual to refer to the main mosque and church in Tual which by the general public is called the city mosque or city church, with the phrase katong pung (we have) church and or katong pung (we have) mosque by both the Christian community and the Muslim community. The phrase "katong pung church" by the Tual Muslim community or the phrase "katong pung mosque" by the Tual Christian community shows how people of different religions in Tual symbolically express their sense of ownership of these buildings, because they are involved in working on them and contributing material within certain limits for the completion of the building. The phrase can also be interpreted as a sense of belonging among groups of people of different religions who are building on the awareness of cultural values and religious values. It also emphasizes awareness about the importance of brotherhood across religious boundaries.

\section{Story 2. Muslim involvement in the priest's conversion to the Catholic Church}

The dedication of a new Catholic priest or pastor among the Kei people is not only a ritual for the Catholic Church and Catholic families, but also a ritual and celebration with interfaith communities in the region. An informant told me that it was a custom among Muslim Kei community members, if there was an ordination of, the pastor's extended family from Muslim villages would follow him, both at home and at church. There are also Muslim families who hold the reception ceremony. From the informant's story it can be concluded that the motivation for the presence of Muslim families at the priest's final ceremony and providing material assistance (yelim) arises from a feeling of ownership. The sense of belonging among Kei Muslims and Christians in the writer's observation is a fundamental reason for looking after one another. The Minister of Religion recognized that when the conflict escalated in Maluku there were some Kei Muslims and Christians provoked by incitement to conflict between them, but this was immediately ended by bringing forward the historical and cultural aspects of the Kei people who had common origins and had great respect for humanity and respect for life together. The form of mutual ownership is caring and compassion for each other.

In relation to the relationship between the Kei indigenous people and ethnic migrants, it was found that the existence of other ethnic groups in the city of Tual did not disturb the "native" Tual residents. In fact, the presence of other ethnic groups helped strengthen the cultural values of the Kei people. In the old harbor and shopping areas, for example, there were many Arabs, Bugis, and Javanese, but one could hardly distinguish them from the original Kei wakga in Tual. This is because they have adjusted their lives to the citizens of Tual. They even call themselves Kei people, and there are no differences in their rights with those from Kei or Evav residents in Tual. This distinguishes people in Tual Kei Kecil from people in other places who tend to differentiate themselves between migrants and native people.

Both stories as they are discovered clearly show that differences in belief and origin in the city of Tual are interpreted as inclusive. Elsewhere, differences in beliefs and origins are often disputed while in Tual the differences are not disputed; instead they are made a joint force to build and maintain social harmony.

\section{Economic Interest Groups}

What is meant by economic interest groups are employees 
(public and private) sellers in traditional and selfservice markets, drivers, port workers and workers in other places who meet and interact with other groups of people on a daily basis. In the writer's observation of economic interest groups, especially in traditional markets and shops around the harbor (or it can be called an old city area), it appears that there are no problems of communication or prejudices between them in each workplace. Everyone conducts activities with a friendly atmosphere full of jokes, like there has never been an open conflict between them. Communities from various ethnic and religious backgrounds come together here for various interests. This activity was carried out until late at night. This condition is different from Ambon City. For example, even though post-conflict intermingling has occurred, segregation of people of different religions is clear. Even in public spaces, such as traditional markets, market activities cannot be carried out until late at night because in addition to the time of rest, residents of the city are still reluctant to move at night.

The economic interest groups referred to in daily interactions using local language or Malay Kei are almost indistinguishable from those of Kei or migrants from outside the Kei Islands. When researchers are with them, everyone is greeted as relatives (turan). The writer even met with a father who came from Nusa Tenggara, who told him that he positioned himself no different from the Kei. Throughout his story, he mentioned his brothers to a number of Kei people, both Muslim and Christian, including some who were known by the author. Apparently, he called them brothers because he was friends with one of their family members and he was accepted as part of the families he called. I also met another person at the port who, when we met, and when he found out my identity, he greeted me as a brother, only because I was from Seram Island. What I want to say from this story is that the people in Tual (= Kei) are people with an open character and can quickly get along with others. They also seem to know stories about the origins and historical events of their ancestors so that it makes them to have high respect for other communities outside the community.

\section{Hobby Groups or Interests Alike}

Starting from the intention of gathering, telling stories, laughing, reminiscing about past stories and channeling hobbies, the result were peaceful community building activities. This statement is the author's conclusion from a number of informal conversations with individuals or community-based interests or hobbies and friends in the city of Tual (Rumahuru, 2019: 54). In the early days of post-conflict recovery, community groups in the city of Tual were both looking for forms of reconciliation, apart from what the government was trying to achieve through a security approach and formal reconciliation formula through meetings between community leaders In this case the community groups in their own way took the initiative to communicate to strengthen the network, and to build shared values to get out of the shackles of discomfort due to conflict in each region.

In the city of Tual there are a number of community activities of the same interests or hobbies, especially among young people, such as the photographic groups, nature lover groups, and art groups. In this study the author pays special attention to the photograph/y community, because this community develops photo talent among young people with a perspective of peace building. This community can be called a community building photo community because of their photo activities that explore peaceful symbols and promote harmony in society. This activity started in 2007 and continues until now and there are a number of photo exhibitions with religious themes that have peaceful educational value. An informant (JD) in Tual said that he saw a special interest among young people to take photos with various perspectives partially. This new hobby is then managed to provide perspective and include education among young people with a photography hobby. After being fostered, the result is that they, on their own initiative, look for funds to buy a standard camera for professionals and take photos of a number of events, and the dynamics of the community are considered to be able to educate the public. Their photos are not only exhibited but also displayed on social media so that they are seen and liked by many people.

Various community activities as mentioned before seem ordinary but have their own strengths among people of different religions who have experienced ethnic social conflict, so that they are able to bridge differences, open barriers of prejudice, build mutual trust between diverse community groups and form social capital and new cultural capital in society. This also shows the dynamics of utilizing an effective cultural approach to conflict resolution, building tolerance and managing diversity among plural societies that should be the strength of the Indonesian nation in dealing with similar conflicts in various regions today and the possibility of conflict due to religious and ethnic differences in the future day.

\section{CONCLUSION}

This study has found two important markers in supporting 
community groups in Tual for building relationships between different religious and ethnic groups. Firstly, three factors were found to influence and support the management of diversity and contribute to the creation of social harmony, namely (1) shared cultural and historical factors, (2) availability of public spaces for encounters, and (3) traumatic transformation. In Tual, there are various tribes and sub-tribes, but each of them can make adjustments to the Kei culture, following the socio-cultural system prevailing in Kei. Cultural values, as contained in the larvul ngabal law, and the philosophy and principles of Kei, ain ni ain, can also be accepted by other communities, ensuring that there are no problems related to cultural differences. In fact, the customary and cultural values of the Kei people effectively become the social and cultural capital that together manage differences and create social harmony. Secondly, the activities carried out by the post-conflict communities in Tual, such as economic groups and interest groups or hobbies, show that what these groups do at first glance seems normal but these activities have an extraordinary impact on the management of diversity and allow for harmony and social support for long-term peace building.

Referring to the findings as presented, this study contributes to the development of conflict and peace studies that use a cultural approach. In many studies of conflict and peace, cultural approaches that prioritize the functioning of local livelihoods as social and cultural capital have not become the primary choice, compared with structural approaches. To explore cultural approaches better, both a theoretical approach and a comprehensive method are needed. This study investigated the factors and forms of community activities that contribute to managing diversity and creating social harmony in postconflict societies. However, a deeper exploration was not made of the aspects of psychology in support of this study.

Furthermore, the authors have not yet analyzed how to use social and cultural capital for long-term peace building, presently choosing instead to focus more on investigating the forms of community activity that support the cessation of conflict and enable efforts to build social harmony, and the factors that influence the building of social harmony. This study nonetheless substantially shows the applicability of local mechanisms and the way community groups form social capital to build post-conflict mutual trust. Therefore, the reality in the community in Tual confirms that a cultural approach is relevant for handling conflicts between groups in society.

\section{ENDNOTES}

1) Larvul Ngabal Law is a customary law governing the way of life of the people in the Kei-Maluku Islands, including rules in relation, ownership to war and its resolution. This law was created by the ancestors of the Kei or Evav people to regulate the life of the Kei community and is still known and enforced to this day. The philosophy of life ain ni ain is a view of Kei life that positions the equality of human life. Maren is a form of social solidarity and cooperation shown by Kei people both to families and to wider groups.

2) Ain ni ain means that all people are the same and vuut ain mehe ni ngunun manut ain mehe ni tilur can be interpreted as everyone coming from a single egg. Both of these expressions mean that Kei people are not distinguished from one another's sweeties. In this perspective the human aspect is highly valued and becomes important for building mutual respect and compassion.

3) This does not mean that the original Kei people are exclusive to groups from outside Kei, because in fact the philosophy of life ain ni ain and lavul ngabal law practiced by the Kei people has inclusive values so that it can be accepted by groups outside the Kei community and become social capital and capital shared culture that can be used for community development in Tual.

\section{REFERENCES}

Abu-Nimer, M. (2001). Conflict Resolution, Culture, and Religion: Toward a Training Model of Interreligious Peacebuilding. Journal of Peace Research, 38(6), 685-704. DOI: 0022343301038006003

Adler, P. S., and S. Kwon. (2002). Social capital: prospects for a new concept. Academy of Management Review, 27(1), 17-40. DOI: $10.2307 / 4134367$

Ahnaf. M.I. (2015). Intoleransi atau Kontestasi: Membaca Ulang Politik Identitas in Ahnaf dkk., Praktik Pengelolaan Keragaman di Indonesia, Kontestasi dan Koeksistensi. Yogyakrta: CRCS, 121-126.

Ahnaf. M.I. \& Lussier, D.N. (2019). Religious Leaders and Elections in the Polarizing Context of Indonesia. Humaniora, 31(3), 227-237. DOI: 10.22146/ jh.v31i3.49420

Aureli, F. (2017). Conflict Resolution. Reference Module in Life Sciences. DOI:10.1016/B978-0-12-8096338.01081-5

Barron, P., Azca M.N., dan Susdinarjanti, R. (2012). Seusai Perang Komunal: Memahami Kekerasan Pasca-Konflik di Indonesia Timur dan Upaya Penanganannya. Yogyakarta: CSPS BOOKS.

Betrand, J. (2004). Nationalism and Ethnic Conflict in Indonesia. USA: Cambridge University Press. 
Bell, G. (2011). Indonesia: The Challenges of Legal Diversity and Law Reform. In E. Black \& G. Bell (Eds.), Law and Legal Institutions of Asia: Traditions, Adaptations and Innovations (pp. 262298). Cambridge: Cambridge University Press. DOI:10.1017/CBO9780511921131.009

Best, R.H. (2018). Legislative Gender Diversity and the Resolution of Civil Conflict. Political Research Quarterly, 72(1), 1-14. DOI: $10.1177 / 1065912918785459$

Coser, Lewis A. (1956). The Fungtion of Social Conflict. New York: The Free Press.

Derwotubun, J. (2018). Telaah Nilai-Nilai Pendidikan Multikultural Dalam Budaya Lokal Masyarakat Kei dan Relevansinya dengan Pendidikan Agama Islam. Unpublished Thesis. IAIN Ambon.

De Jong, E. \& Twikromo, A. (2017). Friction within harmony: Everyday dynamics and the negotiation of diversity in Yogyakarta, Indonesia. Journal of Southeast Asian Studies, 48(1), 71-90. DOI:10.1017/ S0022463416000485

Dhewayani, J. (2016). Managing Religious Diversity in Indonesia: Policy and Reality. In Sofjan (Ed.), Religion, Public Policy and Social Transformation in Southeast Asia. Vol. 1. Managing Religious Diversity. Genewa: Globethics.net. 71-98.

Dionisi, E.R. (2016). Catholic Electoral Partisanship in the Philippines: A Treat to Religious Pluralism? In Sofjan (Ed.), Religion, Public Policy and Social Transformation in Southeast Asia. Vol. 1. Managing Religious Diversity. Genewa: Globethics.net. 225255.

Fidiyani, R. (2013). Kerukunan Umat Bewragama di Indonesia, Belajar Keharmonisan dan Toleransi Umat Beragama di Desa Cikakak, Kec. Wangon, Kab. Banyumas. Jurnal Dinamika Hukum, 13(3), 468-482.

Fisher, R.J. (2015). Conflict and Conflict Resolution. Social Psychology of International Encyclopedia of the Social \& Behavioral Sciences, 2nd edition, Volume 4. DOI: 10.1016/B978-0-08-097086-8.96006-9

Geurtjens, P.H. (2016). Keiesche Legenden: Cerita-Cerita Mayarakat Kei Tempo Dulu. Yogyakarta: Penerbit Gunung Sopai.

Habermas, J. (1984). Theory of Communicative Action. Beacon, Boston.

Hamdi, S. (2017). Conflicting Religious Identities: Blaspheming Islam and The Future of Democracy in Indonesia. $A L A L B A B, 6(2), 247-262$.

Hardiman, Budi F. (2004). Menyimak Filsafat Politik Habermas: Demokrasi Deliberatif: Model Untuk Indonesia Pasca Soeharto? Majalah BASIS No.1112, November-Desember.

Haryanto, J.T. (2014). Kearifan Lokal Pendukung Kerukunan Beragama Pada Komunitas Tengger Malang Jatim.
Analisa, 21(2), 201-213.

Lindgren, T. (2018). Religious Conflicts: Opportunity Structures, Group Dynamics, and Framing. Al-Albab, 7(1), 17-32. doi:https://doi.org/10.24260/alalbab. v7i1.961

Mas'oed, M. (Ed.) (2000). Kekerasan Kolektif, Kondisi dan Pemicu. Yogyakarta: P3PK UGM.

Muhdina, D. (2015). Kerukunan Umat Beragama Berbasis Kearifan Lokal di Kota Makasar. Diskursus Islam, 3(1), 20-36.

Mujiburrahman (2006). Feeling Threatened: MuslimChristian Relations in Indonesia's New Order. ISIM Leiden: Amsterdam University Press.

Nathan, K.S. (2016). Managing Ethnic and Religious Diversity in Malaysia:Implication for Public Policy and Social Transformation. In Sofjan (Ed.), Religion, Public Policy and Social Transformation in Southeast Asia. Vol. 1. Managing Religious Diversity. Genewa: Globethics.net. 43-69.

Panggabeaan, S.R. (2008). Konflik dan Perdamian Etnis di Indonesia. Jakarta: Alvabet dan PUSAD Paramadina.

Pariela, T. (2008). Damai di Tengah Konflik Maluku. Dissertation. Salatiga: Program Pascasarjana Styudi Pembangunan Universitas Kristen Satya Wacana.

Rahawarian, H.Y. (2011). Kerjasama Antar Umat Beragama Dalam Penyelesaian Konflik di Kota Ambon dan Kota Tual Maluku. Unpublished Dissertation. Program Pascasarjana UIN Sunan Kalijaga, Yogyakarta.

Rumahuru, Y.Z. (2005). Peace and Dialogue: Kajian Sosiologi Tentang Dialog dan Inisiatif Damai di Ambon. Thesis, Universitas Gadjah Mada.

Rumahuru, Y.Z. (2016). Relasi antar Kelompok Masyarakat Adat Beda Agama Pasca Konflik di Kota Tual dan Kabupaten Maluku Tenggara: Studi Kasus di Ohoitel dan Elaar. Laporan Penelitian. P3M STAKPN Ambon.

Rumahuru, Y.Z. (2017). Pengelolaan Keragaman Berbasis Masyarakat: Studi Kasus di Kota Tual. Laporan Penelitian. P3M STAKPN Ambon.

Rumahuru, Y.Z. (2019). Dua Kota Satu Cerita: Dinamika Kerukunan dan Pemanfatan Modal Sosial di Ruang Konflik. Yogyakarta: Penerbit Ombak.

Setara Institute (2015). Indeks Kota Toleren (IKT) Tahun 2015. Jakarta: SETARA Institute.

Setara Institute (2016). Indeks Kota Toleren (IKT) Tahun 2016. Jakarta: SETARA Institute.

Setara Institute (2017). Indeks Kota Toleren (IKT) Tahun 2016. Jakarta: SETARA Institute.

Singh, B. (2016). Religion, Multiculturalism and Managing Diversity in Singapore. In Sofjan (Ed.), Religion, Public Policy and Social Transformation in Southeast Asia. Vol. 1. Managing Religious Diversity. Genewa: Globethics.net. 27-42.

Smith, T.G. (2017). Conflict. Politicizing Digital Space: 
Theory. The Internet, and Renewing Democracy, 99-121. DOI: 10.16997/book5.e.

Sofjan, D. (2016). Introduction: Managing Religious Diversity in a Multucultural Southeast Asia. In Sofjan (Ed.), Religion, Public Policy and Social Transformation in Southeast Asia. Vol. 1. Managing Religious Diversity. Genewa: Globethics.net. 13-26.

Soumokil, T. (2011). Integrasi Sosial Pasca Konflik di Maluku. Salatiga: Fakultas Ilmu Sosial dan Ilmu Komunikasi UKSW.

Swidler, L and Mojzes, P. (2000). The Studi of Religion in an Age of Global Dialogue. Philadelphia: Temple University.

Trijono.L., Azca.M.N., Susdinajanti, T., Cahyono,M.F., dan Qodir, Z. (Eds.) (2004). Potret Retak Nusantara, Studi Kasus Konflik di Indonesia. Yogyakarta: CSPS BOOKS.

Ubra, Th. L. (2016). PAK Perdamaian Berbasis Multikultur. Dissertation. STAKPN Ambon.
Ubra, Th. L. (2011). Hamaren: Tipe Ideal Solidaritas Sosial Masyarakat Kepulauan Kei. Semarang: Badan Penerbit Universitas Diponegoro.

Van Klinken, G. (2005). Pelaku Baru Identitas Baru: Kekerasan Antar Suku pada Masa Pasca Soeharto di Indonesia. In Dewi Fprtuna Anwar (Ed.), Konflik Kekerasan Internal, Tinjauan Sejarah, EkonomiPolitik dan Kebijakan di Asia Fasifik. Jakarta: Yayasan Obor Indonesia, KITLV-LIPI-LASEMACNRS.

Van Klinken, G. (2007). Perang Kota Kecil: Kekerasan Komunal dan Demokratisasi di Indonesia. Jakarta: Yayasan Obor Indonesia dan KITLV-Jakarta.

Wagner-Pacifici, R. \& Hall, M. (2012). Resolution of Social Conflict. Annual Review of Sociology, 38, 181-199.

Yusuf, M. (2020). Why Indonesia Prefers A Mono-Religious Education Model? A Durkhemian Perspective. AlAlbab, 9(1), 37-54. doi:https://doi.org/10.24260/ alalbab.v9i1.1555 